\title{
Blood feeding in juvenile Paragnathia formica (Isopoda: Gnathiidae): biochemical characterization of trypsin inhibitors, detection of anticoagulants, and molecular identification of fish hosts
}

\author{
B. M. MANSHIP, A. J. WALKER*, L. A. JONES and A. J. DAVIES \\ School of Life Sciences, Kingston University, Penrhyn Road, Kingston upon Thames, Surrey KT1 2EE, UK
}

(Received 21 Fuly 2011; revised 7 October 2011; accepted 14 November 2011; first published online 6 February 2012)

S UMMARY

The 3 post-marsupial juvenile stages of the gnathiid isopod, Paragnathia formica, are haematophagous ectoparasites of fishes that may, in heavy infestations, cause host mortality. Protein digestion in fed stage 3 juveniles is accomplished by cysteine proteinases, but what bioactive compounds attenuate host haemostatic, inflammatory and immunological responses during feeding is unknown. Trypsin inhibitory activity and anticoagulant activity were detected in crude extracts of unfed $P$. formica stage 1 juveniles; fractionation of stage 1 crude extracts by ion exchange chromatography resulted in 3 preparations each displaying these bioactivities. Further characterization revealed anti-thrombin activity in 2 of these preparations, whilst the third displayed the strongest anticoagulant activity that targeted a factor of the intrinsic coagulation pathway. Three trypsin inhibitors $(18 \mathrm{kDa}, 21 \mathrm{kDa}$, and $22 \mathrm{kDa})$ were also detected using reverse zymography. In parallel, homogenates of fed stage 2 and 3 juveniles were used to identify their fish hosts by amplifying the 16S mitochondrial rDNA and $18 \mathrm{~S}$ genomic rDNA vertebrate gene regions. Blood from at least 4 fish families had been ingested by separate individuals during feeding. This study demonstrates that trypsin inhibitors and anticoagulants are present in $P$. formica juveniles which could suppress host haemostatic, inflammatory and immunological responses during feeding, and that juveniles are not host specific.

Key words: Paragnathia formica, fish ectoparasite, blood feeding, host-parasite interactions, serine protease inhibitor, anticoagulants.

\section{INTRODUCTION}

Gnathiid isopods (Crustacea; Isopoda; Gnathiidae) have biphasic life cycles with free-living adults and parasitic, post-marsupial juvenile stages feeding on fishes. Although approximately 187 gnathiid species have been described world-wide, inhabiting estuaries, intertidal zones, coral reefs, and the deep sea, the impact of blood feeding by their juvenile stages is difficult to assess since they mostly target wild fishes (see Smit and Davies, 2004; Jones et al. 2007; Tanaka, 2007; Manship, 2009; Ferreira et al. 2009, 2010). The parasite-host association can cause host stress, lesions, secondary infections, anaemia, and mortalities in captive environments (see Hayes et al. 2011). Like some terrestrial haematophagous arthropods, gnathiids have also been implicated in the transmission of blood dwelling apicomplexans between fishes, though the route of transmission remains uncertain (see Davies and Smit, 2001; Smit and Davies, 2004; Smit et al. 2006).

\footnotetext{
* Corresponding author: Tel: +44208547 2466. Fax: +44208547 7562. E-mail: t.walker@kingston.ac.uk
}

The present study focuses on the gnathiid Paragnathia formica (Hesse, 1864), which inhabits mud microcliffs in estuaries across Western Europe, North Africa and the Mediterranean Basin (Monod, 1926; Upton, 1987; Cadée et al. 2001; Silva et al. 2006; Kirkim et al. 2008). Adult and juvenile stages can be collected readily from galleries in the mud banks, making this species an excellent gnathiid model for study. Mature females, in contact with water, release unfed zuphea 1 juveniles. These attach to host fish epithelia and, using piercing mouthparts, penetrate host tissues, feeding on whole blood, plasma and possibly mucus, to become inflated praniza 1 stages (Smit and Davies, 2004). As in other gnathiids, three zuphea (unfed) and three praniza stages (fed), as well as adults, occur in the life cycle of $P$. formica.

In fed praniza forms of $P$. formica, the bloodmeal undergoes initial breakdown in the anterior hindgut and protein digestion by cysteine-like proteinases in paired digestive glands (Manship et al. 2008). These processes provide amino acids that enable growth and moulting of praniza stages 1,2 , and 3 to subsequent zuphea 2, and 3 stages, or to adults; they also sustain survival and reproduction of non-feeding adults, and 
support embryological development (see Smit and Davies, 2004; Manship et al. 2011). In some respects the feeding behaviour of gnathiids resembles that of ticks (Ribeiro et al. 1985); P. formica for example can remain attached to the host for hours to days (Stoll, 1962). This association suggests that gnathiids, like ticks, must evade host defence responses, including haemostasis, which limits blood loss by vasoconstriction, platelet aggregation and blood coagulation (Ribeiro and Francischetti, 2003). Blood coagulation in fishes resembles that in higher vertebrates, with an extrinsic pathway stimulated by a tissue factor mostly found in skin, and thrombocytes replacing mammalian platelets in the intrinsic pathway (TavaresDia and Oliveira, 2009; Doolittle, 2011).

While haematophagous aquatic ectoparasites of fishes likely release anti-haemostatic compounds into their hosts during feeding, research on such compounds in these animals is scarce, limited largely to a report by Romestand and Trilles $(1976 a, b)$ demonstrating anti-thrombin activity towards fish blood in the salivary glands of adult cymothoid isopods Meinertia oestroides (Risso, 1826) and Anilocra physodes (Linnaeus, 1758) (Isopoda: Cymothoidae). Because zuphea 1 stages of $P$. formica have well developed salivary glands, even before hatching from females (Manship et al. 2011), we hypothesized that these glands might produce pharmacological compounds such as anticoagulants to facilitate blood feeding by $P$. formica. Here, we demonstrate for the first time the partial purification of trypsin inhibitors, and anticoagulant activities partly targeting thrombin, in recently-hatched $P$. formica zuphea 1 juveniles.

As in ticks (Pichon et al. 2003), gnathiids parasitize a variety of hosts, sometimes demonstrating micropredatory behaviour, though little is known of their host-selectivity. Such knowledge could be vital for assessing the impact of their feeding behaviour in various ecosystems, for instance on the Great Barrier Reef (GBR), Australia (Nagel and Lougheed, 2006; Jones et al. 2007), or on the transmission of apicomplexan parasites (Smit and Davies, 2004; Smit et al. 2006). Host specificity in some gnathiids of the genus Gnathia Leach, 1814 has been partially addressed on the GBR, by sequencing specific vertebrate $12 \mathrm{~S}$ and $16 \mathrm{~S}$ rDNA mitochondrial gene regions from fed (praniza) gnathiids (Nagel and Lougheed, 2006; Jones et al. 2007). To date, several $P$. formica host fishes have been recorded from the wild (Monod, 1926; Menezes, 1984; Kirkim et al. 2008), and in laboratory feeding experiments (Monod, 1926), which suggest that this gnathiid is relatively host non-specific. Here, we verify that several host fishes can be identified from the bloodmeal content of praniza juveniles collected from two sites in the UK, using PCR amplification targeting conserved gene sequences, namely $16 \mathrm{~S}$ rDNA and 18S rDNA gene regions.
MATERIALS AND METHODS

\section{Specimen sampling, maintenance and storage}

Paragnathia formica praniza 2 and 3 juveniles $(n=7)$ and gravid females $(n=\sim 600)$ were collected from salt marsh banks of the type described by Manship et al. (2008, 2011) at Wells-next-the-Sea, Norfolk (Ordnance Survey grid reference, TF 925 438) (see Tinsley and Reilly, 2002) during April and May, and from the Dovey Estuary, Wales (Ordnance Survey grid reference, SN 674 973) during July and September. Live praniza juveniles were rinsed in distilled water, fixed in ice cold $70 \%$ ethanol and stored at $4{ }^{\circ} \mathrm{C}$. Live females were maintained on damp tissue paper (in the dark) at $16^{\circ} \mathrm{C}$ in an incubator, and were transferred to sea water, once mature, for release of motile zuphea 1 juveniles. Spent females were removed from the sea water, whilst the unfed juveniles were further maintained in sea water for 1 week (Tinsley and Reilly, 2002). After rinsing in distilled water, zuphea 1 juveniles (approximately $1 \mathrm{~g}$ in total, or $\sim 53 \times 10^{3}$ individuals) were collected on absorbent filter paper, snap frozen in liquid nitrogen and stored at $-80^{\circ} \mathrm{C}$.

\section{Biochemical analyses and semi-purification of trypsin inhibitors and anticoagulants from unfed zuphea 1 stages}

Zuphea 1 forms were selected since only the newly hatched juvenile stages of $P$. formica could be harvested in sufficient numbers to permit biochemical analyses of trypsin inhibitors and anticoagulants. Approximately $1 \mathrm{~g}$ of zuphea 1 stages stored at $-80{ }^{\circ} \mathrm{C}$ (above) were homogenized in a sterile Potter homogenizer on ice in $5 \mathrm{ml}$ of $50 \mathrm{mM}$ Tris- $\mathrm{HCl}$ buffer, $\mathrm{pH} 8 \cdot 5$, containing $20 \mathrm{mM} \mathrm{NaCl}$ (Morris and Sakanari, 1994; Azzolini et al. 2003), centrifuged at $14000 \mathrm{~g}$ for $5 \mathrm{~min}$ at $4^{\circ} \mathrm{C}$, and the crude extract $(\mathrm{CE})$ protein concentrations measured using the Bio-Rad DC microassay according to the manufacturer's instructions.

The inhibitory effect of the zuphea $1 \mathrm{CE}$ (approximate protein concentration $=10-14 \cdot 5 \mu \mathrm{g} / \mu \mathrm{l}$ ) on the proteolytic activity of trypsin towards the fluorogenic serine protease substrate N-carbobenzoxy-Gly-ProArg-4-methoxy-2-naphthylamine (Z-gly-pro-argMNA; Bachem) was then determined according to Morris and Sakanari (1994) and Azzolini et al. (2003). Varying amounts of CE $(0 \mu \mathrm{g}$ (control), $0 \cdot 2 \mu \mathrm{g}, 1 \mu \mathrm{g}, 2 \mu \mathrm{g}, 5 \mu \mathrm{g} 10 \mu \mathrm{g}, 20 \mu \mathrm{g}, 50 \mu \mathrm{g}$, and $100 \mu \mathrm{g}$ ) were pre-incubated for $15 \mathrm{~min}$ at room temperature with $1 \mathrm{nM}(0.006 \mathrm{U})$ trypsin from bovine pancreas (Calbiochem) in $50 \mathrm{mM}$ Tris- $\mathrm{HCl}$ buffer, $\mathrm{pH} 7 \cdot 5$, within individual wells of a microtitre plate; $10 \mu \mathrm{l}$ of Z-gly-pro-arg-MNA $(0.1 \mathrm{mM}$ final concentration in $100 \mu$ l total reaction volume) were then added and the released MNA (excitation $355 \mathrm{~nm}$, emission $420 \mathrm{~nm}$ ) measured over $2 \mathrm{~h}$ at 
$25^{\circ} \mathrm{C}$ using a Fluostar Optima reader (BMG Labtech). The inhibitory capacity of the $\mathrm{CE}$ on the hydrolysis of $0.1 \mathrm{mMZ}$-gly-pro-arg-MNA (Bachem) by thrombin was determined by pre-incubating $50 \mathrm{nM}(0.009 \mathrm{U})$ bovine thrombin (Calbiochem) with $20 \mu \mathrm{g}$ CE for $15 \mathrm{~min}$ at room temperature in $50 \mathrm{mM}$ Tris- $\mathrm{HCl}$ buffer, $\mathrm{pH} 7 \cdot 5$. The reaction was initiated by adding the substrate $(0 \cdot 1 \mathrm{mM}$ final concentration in $100 \mu$ l total reaction volume) and inhibition measured as for the trypsin inhibitor assays.

Effects of the zuphea $1 \mathrm{CE}$ on the recalcification time and fibrinogen clotting time of human plasma were assayed according to Ricci et al. (2007). For recalcification time, $25 \mu \mathrm{l}$ citrated human plasma (Sigma) were incubated at room temperature in $50 \mathrm{mM}$ Tris-HCl buffer (final volume $70 \mu \mathrm{l}$ ), $\mathrm{pH} 7 \cdot 5$, containing $0 \mu \mathrm{g}$ (control), $14 \cdot 5 \mu \mathrm{g}, 29 \cdot 1 \mu \mathrm{g}$, or $72.5 \mu \mathrm{g}$ zuphea $1 \mathrm{CE}$. After $5 \mathrm{~min}$, coagulation was initiated by adding $5 \mu \mathrm{l} 150 \mathrm{mM} \mathrm{CaCl}_{2}$, and clot formation was continuously measured in microtitre plates at $25^{\circ} \mathrm{C}$ for $30 \mathrm{~min}$ at $620 \mathrm{~nm}$ with a Fluostar Optima reader. For the fibrinogen clotting assay, $6 \cdot 5 \mu \mathrm{M}$ fibrinogen from human plasma (Calbiochem) was incubated at room temperature in $50 \mathrm{mM}$ Tris- $\mathrm{HCl}$ buffer (total incubation volume of $90 \mu \mathrm{l}$ ), $\mathrm{pH} 7 \cdot 5$, containing $0 \mu \mathrm{g}$ (control), $14 \cdot 5 \mu \mathrm{g}$ or $72 \cdot 5 \mu \mathrm{g}$ CE. After $5 \mathrm{~min}, 10 \mu \mathrm{l}$ of a $0 \cdot 54 \mu \mathrm{M}(2 \cdot 2 \mathrm{U})$ solution of thrombin from human plasma (Calbiochem) were added to trigger clot formation, which was measured at $620 \mathrm{~nm}$, as described for the recalcification time; the final absorbances measured were subtracted from values obtained at $0 \mathrm{~min}$.

The zuphea $1 \mathrm{CE}$ was then applied to a Nap-25 column (GE Healthcare) at $4{ }^{\circ} \mathrm{C}$ according to the manufacturer's instructions. Fractions collected from the Nap-25 column displaying inhibitory activity were pooled, and concentrated to $1 \mathrm{ml}$ using a Vivapore ${ }^{\circledR}$ concentrator (Vivascience). In an attempt to purify the bioactive compound(s) from the zuphea 1 homogenate, the concentrated sample was applied to a $1 \mathrm{ml}$ Sepharose anion-exchange chromatography column (HiTrap Q) (GE Healthcare) at $4{ }^{\circ} \mathrm{C}$ preequilibrated with Tris- $\mathrm{HCl}$ wash buffer (Tanaka et al. 1999). This resin was used since its working $\mathrm{pH}$ range is optimal for the stability of trypsin and trypsin inhibitors. After washing with $50 \mathrm{mM}$ Tris- $\mathrm{HCl}, \mathrm{pH} 8 \cdot 5$, at $1 \mathrm{ml} / \mathrm{min}$, bound proteins were eluted with $50 \mathrm{mM}$ Tris- $\mathrm{HCl}, \mathrm{pH} 8 \cdot 5$, containing a $\mathrm{NaCl}$ gradient of $0-0.5 \mathrm{M}$ (in $10 \mathrm{mM}$ increments), and $1 \mathrm{ml}$ fractions collected on ice. Three major peaks (P1, P2, and P3) of trypsin inhibitory activity were obtained and concentrated.

To determine the size of the trypsin inhibitors isolated in the fraction displaying the strongest trypsin inhibitory activity, $6 \cdot 5 \mu \mathrm{g}$ P1 were loaded onto $15 \%$ SDS-PAGE gels, either containing $0 \cdot 1 \%$ $(\mathrm{w} / \mathrm{v})$ gelatin or not, and those with gelatin processed for reverse zymography according to Hanspal et al.
(1983) and Andreotti et al. (2002). The gel was electrophoresed at $4{ }^{\circ} \mathrm{C}$ at $140 \mathrm{~V}$, and subsequently washed in $0 \cdot 1 \mathrm{M}$ Tris- $\mathrm{HCl}, \mathrm{pH} 8 \cdot 0$, containing $2 \cdot 5 \%$ $(\mathrm{v} / \mathrm{v})$ Triton $\mathrm{X}-100$ for $1 \mathrm{~h}$. The gel was then rinsed in distilled water and incubated at $37^{\circ} \mathrm{C}$ for $90 \mathrm{~min}$ in $25 \mathrm{ml}$ of $0 \cdot 1 \mathrm{M}$ Tris-HCl buffer, $\mathrm{pH} 8 \cdot 0$, containing $87 \mu \mathrm{M}(125000 \mathrm{U})$ bovine trypsin. The gel was then rinsed in distilled water and stained with Coomassie brilliant blue to reveal bands corresponding to the molecular weight(s) of the trypsin inhibitors.

Finally, the effects of the semi-purified preparations on human plasma and fibrinogen clotting times were determined as described above. Briefly, $2.7 \mu \mathrm{g}, 7.6 \mu \mathrm{g}$ and $8.1 \mu \mathrm{g}$ of $\mathrm{P} 1, \mathrm{P} 2$, and $\mathrm{P} 3$, respectively, were assayed for their effects on recalcification time (at $50 \%$ clot formation) and fibrinogen clotting time (at 50\% clot formation), against buffer in control wells. In the case of the recalcification time, $2.7 \mu \mathrm{g}$ P1 (possessing the greatest anticoagulant activity) were boiled for $10 \mathrm{~min}$ prior to conducting the assay to verify whether the anticoagulant(s) could be heat denatured, and thus, be proteinaceous.

All enzyme/coagulation assays were carried out in triplicate, and one-way analyses of variance (ANOVA) and post-hoc multiple comparison tests (Least Significant Difference, LSD) were done on data obtained.

\section{Molecular typing of vertebrate DNA from fed praniza juveniles}

Zuphea 1, and subsequent zuphea 2 and 3 stages of $P$. formica feed on fishes, becoming pranizae 1, 2 and 3 respectively. Thus, to investigate the source of host blood in the juvenile gnathiid digestive tract, larger fed praniza $2(2-2.5 \mathrm{~mm})$ and $3(3-3.5 \mathrm{~mm})$ stages were employed. A set of universal (vertebrate and invertebrate) primers targeting the mitochondrial large subunit ribosomal DNA (16Sar and 16Sbr) (Simon, 1991), as well as the eukaryote conserved 18SA (Blakenship and Yayanos, 2005) primer and a reverse $18 \mathrm{~S}$ primer modified from Dreyer and Wägele (2001) to anneal the genomic small subunit ribosomal DNA of fishes, were used. DNA was extracted from blood-filled, individual, praniza juveniles using a protocol modified from Sicard et al. (2001) and Jones et al. (2007). Briefly, specimens were rinsed in distilled water and placed individually in sterile microfuge tubes containing $200 \mu \mathrm{l}$ DNA extraction

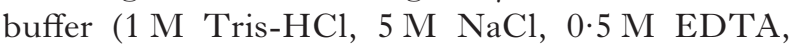
$0 \cdot 2 \%(\mathrm{v} / \mathrm{v}) \beta$-mercaptoethanol, and $5 \%(\mathrm{v} / \mathrm{v}) \mathrm{CTAB})$. Specimens were then homogenized using sterile plastic pestles (Anachem) and incubated for $1 \mathrm{~h}$ at $55^{\circ} \mathrm{C}$, prior to the addition of $200 \mu \mathrm{l}$ of chloroform. After centrifugation, the aqueous phase containing genomic DNA was added to $200 \mu \mathrm{l}$ of ice-cold isopropanol to precipitate the DNA. After rinsing in $70 \%$ ethanol, precipitated nuclear material was 


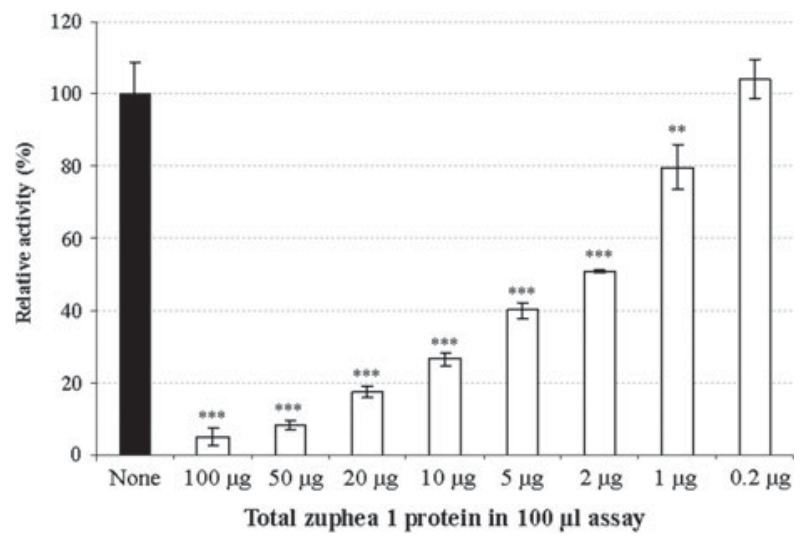

Fig. 1. Effect of varying amounts of Paragnathia formica zuphea 1 crude extract (CE) on the hydrolysis of $0 \cdot 1 \mathrm{mM}$ Z-gly-pro-arg-MNA by $1 \mathrm{nM}$ trypsin. Bars represent mean values of 3 replicates ( \pm s.D.), from both control ( $\square)$ and $\mathrm{CE}(\square)$ assays. ${ }^{* *} P<0.01$ and ${ }^{* * *} P<0.001$ when compared to control values.

re-pelleted and re-suspended in $15 \mu 1$ of diethylpyrocarbonate (DEPC)-treated water.

Extracted DNA ( $5 \mu \mathrm{l}$ per $50 \mu \mathrm{l}$ assay) was amplified using the BD TITANIUM ${ }^{\mathrm{TM}}$ Taq (BD Biosciences), and primers noted above, following the cycling programme used by Jones et al. (2007). The $\sim 600-$ $650 \mathrm{bp} 16 \mathrm{~S}$ rDNA and $\sim 300-350 \mathrm{bp} 18 \mathrm{~S}$ rDNA bands were extracted from the agarose gel using a QIAquick gel extraction kit (Qiagen), and sequenced at the Natural History Museum (South Kensington, London).

Sequences were entered into the Basic Local Alignment Search Tool (BLAST) (http://www.ncbi. nlm.nih.gov/BLAST/) in order to obtain matching sequences (McGinnis et al. 2004). The amplified sequences were subsequently aligned against the closest matching sequences using CLUSTAL W (http://clustalw.genome.jp/) ('Thompson et al. 1994), and whenever sequence manipulation was required the molecular toolkit program (http://www.vivo. colostate-edu/molkit/manip/) was employed. FishBase (http://www.fishbase.org/) was scrutinised to verify whether matching fish species were compatible hosts for gnathiids inhabiting the Atlantic coast and North Sea coast.

\section{RESULTS}

\section{Characterization of trypsin inhibitors and anticoagulants from zuphea 1 extracts}

Crude zuphea 1 extracts were assayed for the presence of trypsin or thrombin inhibitors using the serine protease substrate $Z$-gly-pro-arg-MNA. The proteolytic activity of trypsin towards this substrate was inhibited significantly by over $80 \%(P<0 \cdot 001)$ after pre-incubation in buffer containing $20 \mu \mathrm{g}$ zuphea $1 \mathrm{CE}$, whereas the proteolytic activity of thrombin towards the same substrate diminished by
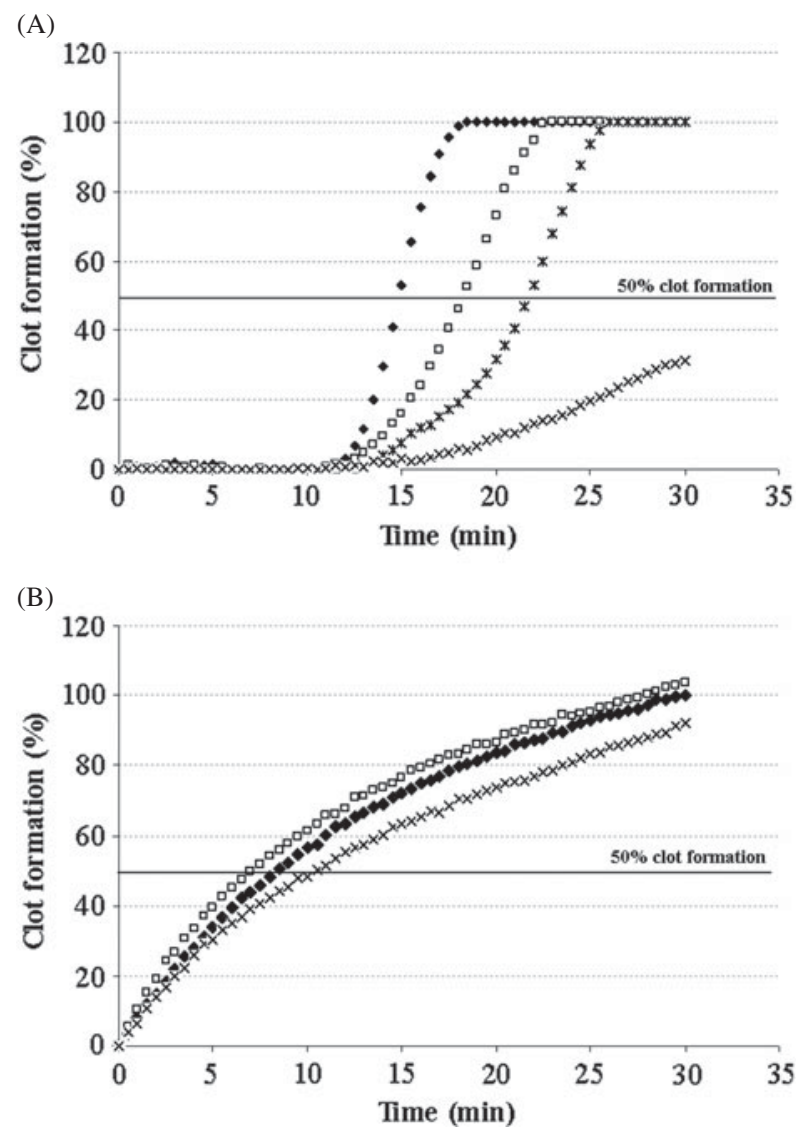

Fig. 2. Anticoagulant properties of Paragnathia formica zuphea 1 crude extract (CE). (A) Recalcification time of human plasma in the absence $(\downarrow)$ or presence of $14 \cdot 5 \mu \mathrm{g}(\square), 29 \cdot 1 \mu \mathrm{g}(*)$, or $72 \cdot 5 \mu \mathrm{g}(\times)$ of zuphea $1 \mathrm{CE}$; (B) Fibrinogen clotting time of human fibrinogen in the absence $(\diamond)$ or presence of $14.5 \mu \mathrm{g}(\square)$, or $72.5 \mu \mathrm{g}(\times)$ of zuphea $1 \mathrm{CE}$. Data represent the mean values of 3 replicates.

approximately $30 \% \quad(P<0 \cdot 01)$ (data not shown). Owing to the higher level of trypsin inhibition, compared to thrombin inhibition by the zuphea $1 \mathrm{CE}$, subsequent experiments focused primarily on trypsin inhibition. A dose-dependent inhibition of trypsin activity by the CE was observed; Z-glypro-arg-MNA hydrolysis by trypsin was reduced by $50 \%$ with $2 \mu \mathrm{g}$ CE $(P<0.001), 91 \cdot 6 \%$ with $50 \mu \mathrm{g} \mathrm{CE}$ $(P<0 \cdot 001)$, and over $95 \%$ with $100 \mu \mathrm{g} \mathrm{CE}(P<0 \cdot 001)$; in contrast no inhibition was observed with $0 \cdot 2 \mu \mathrm{g} \mathrm{CE}$ (Fig. 1).

To assess the effect of the zuphea $1 \mathrm{CE}$ on coagulation of human plasma, a coagulation assay estimating the recalcification time of human plasma was conducted. The mean time to reach 50\% clot formation in the control sample was $15 \mathrm{~min}$ $10 \mathrm{~s}$. Pre-incubation with $14 \cdot 5 \mu \mathrm{g}$ or $29 \cdot 1 \mu \mathrm{g}$ zuphea 1 CE prolonged $50 \%$ clot formation by $3 \mathrm{~min} 20 \mathrm{~s}$ $( \pm 52 \mathrm{~s})$ and $6 \mathrm{~min} 10 \mathrm{~s}( \pm 2 \mathrm{~min} 30 \mathrm{~s})$, respectively, representing mean increases of $22 \%$ and $40 \cdot 7 \%$ (Fig. 2A). Moreover, pre-incubation with, $72.5 \mu \mathrm{g}$ $\mathrm{CE}$ inhibited clot formation entirely over $30 \mathrm{~min}$ (Fig. 2A). To substantiate the inhibitory activity of 


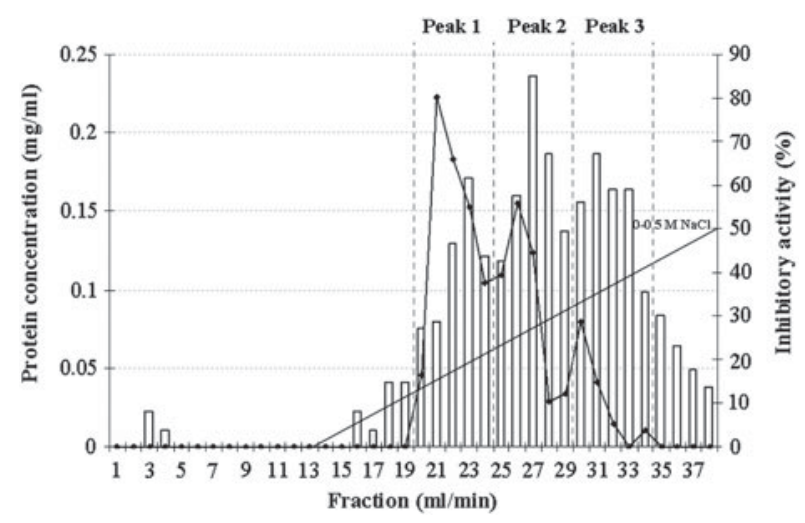

Fig. 3. Protein concentration (bars) and trypsin inhibitory activity ( ) of Paragnathia formica zuphea 1 fractions collected from a HiTrap Q ion-exchange chromatography column. Approximately $15 \mathrm{mg}$ of zuphea 1 protein recovered from the Nap-25 gel filtration column were passed through the HiTrap Q column at a flow rate of $1 \mathrm{ml} / \mathrm{min}$. Proteins captured by the column were eluted after 13 min by applying increasing $\mathrm{NaCl}$ concentrations ( 0 to $0.5 \mathrm{M}$ in $0.01 \mathrm{M}$ increments every $30 \mathrm{~s}$ ). The fractions were recovered, protein concentration measured and $10 \mu \mathrm{l}$ of each fraction incubated with $1 \mathrm{nM}$ trypsin for 15 min prior to the addition of $0 \cdot 1 \mathrm{mM} \mathrm{Z}$-gly-pro-argMNA to determine trypsin inhibitory activity. Three inhibitory peaks were detected (delineated by the dotted vertical lines), each comprising 5 fractions, between $0 \cdot 15-0 \cdot 23 \mathrm{M} \mathrm{NaCl}(\mathrm{P} 1), 0 \cdot 24-0 \cdot 33 \mathrm{M} \mathrm{NaCl}(\mathrm{P} 2)$ and $0 \cdot 34-0 \cdot 43 \mathrm{M} \mathrm{NaCl}(\mathrm{P} 3)$.

zuphea $1 \mathrm{CE}$ towards thrombin seen in the fluorimetric assays, and to characterize further the anticoagulant effect, fibrinogen was pre-incubated with zuphea $1 \mathrm{CE}$ prior to the addition of thrombin. After $30 \mathrm{~min}, 72 \cdot 5 \mu \mathrm{g}$ CE prolonged $50 \%$ fibrinogen clot formation by $1 \mathrm{~min} 40 \mathrm{~s}$ ( $\pm 1 \mathrm{~min}$ ) compared to the uninhibited control wells that possessed a mean $50 \%$ clotting time of $8 \mathrm{~min} 40 \mathrm{~s}$; no delay was seen with $14 \cdot 5 \mu \mathrm{g}$ CE per assay (Fig. 2B).

Zuphea 1 protein $(30 \mathrm{mg}$ ) was desalted using a Nap-25 column and subsequently applied to a HiTrap Q column. A total of 3-4 $\mathrm{mg}$ of zuphea 1 protein was collected in 38 fractions (Fig. 3), and 3 major protein peaks corresponding to 3 separate trypsin inhibitory peaks were eluted off the HiTrap Q column between $0 \cdot 15-0 \cdot 23 \mathrm{M} \mathrm{NaCl}(\mathrm{P} 1), 0 \cdot 24-0 \cdot 33 \mathrm{M}$ $\mathrm{NaCl}$ (P2), and 0.34-0.43 M NaCl (P3) (Fig. 3). The fractions within each of these peaks of trypsin inhibition were then pooled. Preparations from peaks 2 and 3 (P2 and P3) had greater protein concentrations $0 \cdot 76 \mu \mathrm{g} / \mu \mathrm{l}$ and $0 \cdot 81 \mu \mathrm{g} / \mu \mathrm{l}$, compared to that of P1 $(0 \cdot 27 \mu \mathrm{g} / \mu \mathrm{l})$; however, they displayed lower trypsin inhibitory activities. Indeed, $2 \mu \mathrm{l} \mathrm{P} 2(1.52 \mu \mathrm{g}$ zuphea 1 protein) and P3 (1.62 $\mu \mathrm{g}$ zuphea 1 protein) inhibited trypsin hydrolysis by $28 \cdot 2 \% \pm 6 \cdot 4 \%$ $(P<0.05)$ and $44 \cdot 1 \% \pm 2.5 \%(P<0 \cdot 05)$, respectively, whereas $5 \mu \mathrm{l}(1 \cdot 35 \mu \mathrm{g}$ zuphea 1 protein) $\mathrm{P} 1$ reduced trypsin hydrolysis by $84 \cdot 25 \% \pm 0 \cdot 46(P<0 \cdot 001)$ (data not shown). Similar levels of trypsin inhibition were
(A)

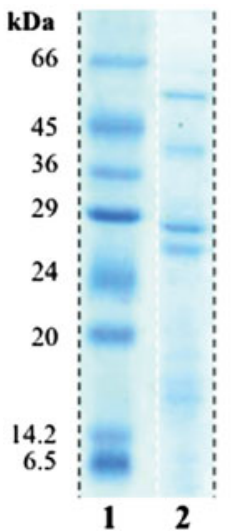

(B)

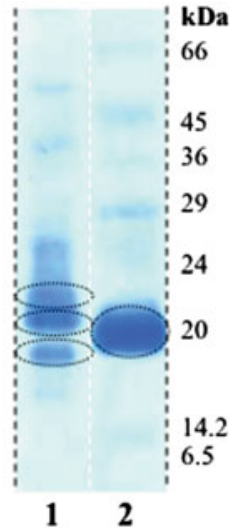

Fig. 4. (A) Coomassie-stained SDS-PAGE gel showing the low molecular weight ladder (lane 1 ), and $6.5 \mu \mathrm{g}$ Paragnathia formica zuphea 1 peak 1 collected from the HiTrap Q ion-exchange chromatography column (lane 2). (B) Coomassie stained reverse zymography gel showing the trypsin inhibitory activity of $6 \cdot 5 \mu \mathrm{g}$ peak 1 (lane 1 ) and the low molecular weight ladder, in particular the inhibitory activity of SBTI at $\sim 20 \mathrm{kDa}$ (lane 2). Trypsin inhibitors were detected using $15 \%$ polyacrylamide resolving gels containing $0 \cdot 1 \%$ gelatin. After electrophoresis at $4{ }^{\circ} \mathrm{C}$, the gels were incubated for $90 \mathrm{~min}$ in $87 \mu \mathrm{M}$ trypsin at $37^{\circ} \mathrm{C}$. Undigested areas by the trypsin produced diffuse inhibition zones, similar to the $\sim 20 \mathrm{kDa}$ band produced by approximately $2 \cdot 2 \mu \mathrm{g}$ SBTI contained in the low molecular weight ladder.

obtained using $2.7 \mu \mathrm{g}$ of the semi-purified preparation P1 to those observed using $50 \mu \mathrm{g}$ zuphea $1 \mathrm{CE}$ (Fig. 1), indicating that the partial purification of the trypsin inhibitor(s) from the crude extract was successful.

Following the partial purification of trypsin inhibitor(s) in the zuphea $1 \mathrm{CE}$, reverse zymography was done using protein from the most active peak (P1) to determine the sizes of the trypsin inhibitor(s) present. Soybean trypsin inhibitor (SBTI) (20 kDa) in the molecular weight markers served as a positive control. The large diffuse band obtained (Fig. 4B, lane 2) corresponded to the location of SBTI (Fig. 4A, lane 1) after trypsin digestion of the gelatin within the gel. In the case of the semi-purified zuphea 1 P1, 3 smaller diffuse bands were obtained with apparent molecular weights of $\sim 18 \mathrm{kDa}, \sim 21 \mathrm{kDa}$ and $\sim 22 \mathrm{kDa}$ (Fig. 4B, lane 1), which did not seem to correspond to any of the 6 major bands seen on the SDS-PAGE gel (Fig. 4A, lane 2). This suggests that although present in low concentrations, the inhibitors have potent inhibitory activity.

The anticoagulant properties of the semi-purified fractions were assayed alongside their trypsin inhibitory activities. Of the 3 preparations obtained, preparation P1 possessed the greatest anticoagulant activity, with $2.7 \mu \mathrm{g}$ zuphea 1 protein delaying recalcification time of human plasma (mean time to $50 \%$ clot formation of $15 \mathrm{~min} 10 \mathrm{~s}$ ) by $6 \mathrm{~min} 40 \mathrm{~s}$ $( \pm 3 \mathrm{~min} 30 \mathrm{~s})$, representing a $44 \%(P<0.05)$ increase 
(A)

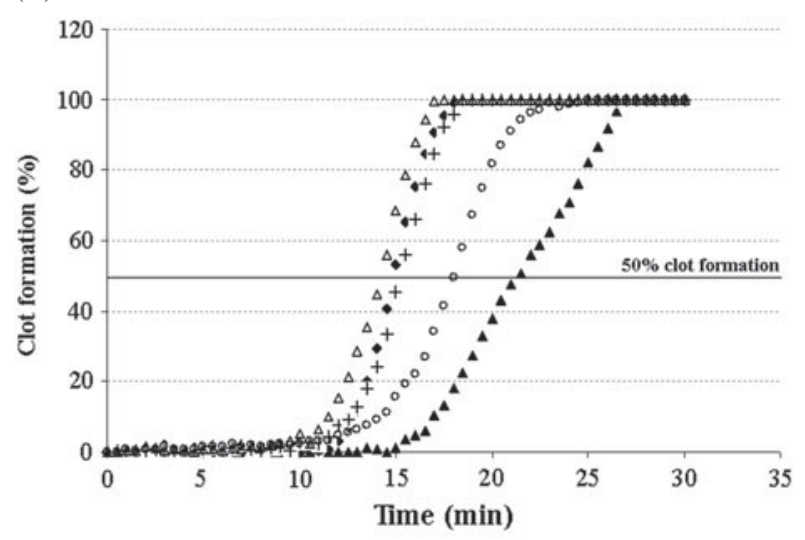

(B)

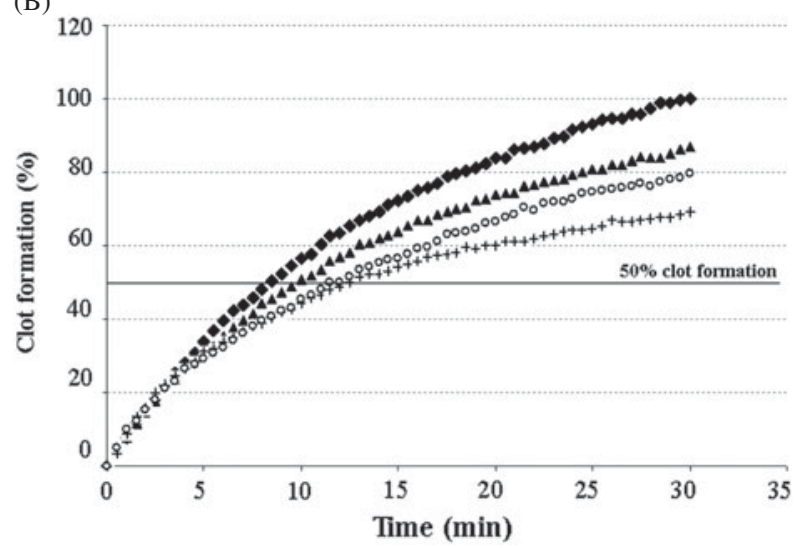

Fig. 5. (A) Effect of Paragnathia formica zuphea 1 semi-purified proteins on the recalcification time of human plasma after pre-incubation of plasma with $0 \mu \mathrm{g}$ zuphea 1 protein from semi-purified peaks $(\$), 2.7 \mu \mathrm{g}$ P1 ( $\mathbf{\Delta}), 7 \cdot 6 \mu \mathrm{g}$ P2 (+), or $8 \cdot 1 \mu \mathrm{g} \mathrm{P} 3(\mathrm{O})$, as well as $2.7 \mu \mathrm{g}$ zuphea 1 peak 1 previously boiled for $10 \mathrm{~min}$ at $100^{\circ} \mathrm{C}$ $(\Delta)$. (B) Effect of $P$. formica zuphea 1 semi-purified proteins on the fibrinogen clotting time of human fibrinogen after pre-incubation with $0 \mu \mathrm{g}$ zuphea 1 protein from semi-purified peaks $(\diamond), 2 \cdot 7 \mu \mathrm{g}$ P1 ( $\mathbf{\Delta}), 7 \cdot 6 \mu \mathrm{g}$ P3 $(+)$, or $8 \cdot 1 \mu \mathrm{g} \mathrm{P} 3(\mathrm{O})$. Data represent the mean values of 3 replicates.

(Fig. 5A). In contrast, $8 \cdot 1 \mu \mathrm{g}$ P3 delayed recalcification time by $2 \mathrm{~min} 50 \mathrm{~s} \mathrm{(} \pm 1 \mathrm{~min}$ ) or $18 \cdot 7 \%$, and $7 \cdot 6 \mu \mathrm{g}$ P2 did not delay $50 \%$ clot formation compared to control samples (Fig. 5A). However, both P2 and P3 preparations displayed anti-thrombin activities in fibrinogen clotting assays, since the duration to $50 \%$ clot formation was delayed by $4 \min ( \pm 2 \min 10 \mathrm{~s}$ ) or $46 \cdot 2 \%$, and by $4 \mathrm{~min} 10 \mathrm{~s}$ ( $\pm 4 \mathrm{~min} 20 \mathrm{~s}$ ) or $48 \cdot 1 \%$, respectively compared to the mean control clot formation time ( $8 \mathrm{~min} 40 \mathrm{~s}$ ) (Fig. $5 \mathrm{~B}$ ). Only a slight increase $15 \cdot 4 \%( \pm 5 \cdot 8 \%)$ in delay in fibrinogen clotting time could be attributed to $\mathrm{P} 1$, and although the protein concentration in this preparation was lower than in P2 and P3, inhibitory activity towards thrombin in this preparation again appeared to follow that observed in the $\mathrm{CE}$ (Figs $2 \mathrm{~B}$ and $5 \mathrm{~B}$ ). This is supportive of zuphea 1 anti-thrombin compound(s) being present in small amounts and primarily in $\mathrm{P} 2$ and P3, and that the predominant anticoagulant(s) contained in the CE were present in P1. Finally, the anticoagulant activity observed in P1 was heat denatured (Fig. 5A) and this no longer inhibited the recalcification time of human plasma, suggesting that the anticoagulant(s) are proteinaceous.

\section{Molecular identification of fish hosts from praniza bloodmeals}

Fish DNA sequences amplified best with the mitochondrial 16S rDNA primers from $P$. formica praniza 3 juveniles collected at Wells-next-the-Sea, revealing 3 host families, including the Anguillidae, Clupeidae, and Pleuronectidae (Table 1). Furthermore, the $16 \mathrm{~S}$ rDNA gene region identified hosts successfully to genus and species level, with over 99\% homology to the European eel, Anguilla anguilla (Linnaeus, 1758), 95-98\% homology to the Atlantic herring, Clupea harengus Linnaeus, 1758, and 98-99\% homology to the European flounder, Platichthys flesus (Linnaeus, 1758), all fish species native to North Sea shores.

Two host families were identified from praniza 2 and 3 specimens from the Dovey Estuary using the $18 \mathrm{~S}$ rDNA primers (Table 1). Two pranizae had fed on hosts belonging to the Pleuronectidae, the closest matching fish (with over 97\% and 99\% homology) being the stone flounder, Kareius bicoloratus (Basilewsky, 1855), a Pacific Ocean fish (Table 1). However, the European plaice, Pleuronectes platessa Linnaeus, 1758 , has a shorter $18 \mathrm{~S}$ rDNA sequence than the stone flounder, but shares similar homologies (99\% and $97 \%$, respectively) with the 2 sequences obtained from the gnathiid gut contents (Table 1) and is a much more likely host in this instance. In a similar manner, a third praniza collected from the Dovey Estuary had apparently fed upon a member of the Scombridae, and in this case the closest match was the bullet tuna, Auxis rochei (Risso, 1810) ('Table 1). Since this tuna occurs on European Atlantic coasts, but does not inhabit estuaries, it appears more likely that the gnathiid had fed on another scombrid. Thus, it seems that the $18 \mathrm{~s}$ rDNA gene region selected was too conserved to identify hosts reliably to genus and species level, and the host species listed as the closest matching organisms in the BLAST results were a consequence of better sequence coverage rather than sequence homology.

\section{DISCUSSION}

We report for the first time, partial purification by anion-exchange chromatography of different bioactive compounds from homogenates of newly hatched $P$. formica zuphea 1 juveniles which could attenuate host haemostatic, inflammatory and immunological responses. Preliminary trypsin/thrombin 
Table 1. Identification of vertebrate fish host from the bloodmeal content of praniza 2 and praniza 3 juveniles of Paragnathia formica collected from Wells-next-the-Sea (see Tinsley and Reilly, 2002) and the Dovey Estuary (see Manship et al. 2008)

\begin{tabular}{|c|c|c|c|c|}
\hline Bloodmeal origin & Targeted genes & Host Family & Homology & Closest matching organism \\
\hline Wells-next-the-Sea & $16 \mathrm{~S}$ rDNA & $\begin{array}{l}\text { Anguillidae } \\
\text { Pleuronectidae } \\
\text { Clupeidae } \\
\text { Pleuronectidae }\end{array}$ & $\begin{array}{l}99 \% \\
99 \% \\
98 \% \\
98 \%\end{array}$ & $\begin{array}{l}\text { Anguilla anguilla }{ }^{\mathrm{a}} \\
\text { Platichthys flesus }^{\mathrm{a}} \\
\text { Clupea harengus }^{\mathrm{a}} \\
\text { Platichthys flesus }\end{array}$ \\
\hline Dovey Estuary & $18 \mathrm{~S}$ rDNA & $\begin{array}{l}\text { Pleuronectidae } \\
\text { Scombridae } \\
\text { Pleuronectidae }\end{array}$ & $\begin{array}{l}99 \% \\
97 \% \\
97 \%\end{array}$ & $\begin{array}{l}\text { Kareius bicoloratus } \\
\text { Auxis rochei } \\
\text { Kareius bicoloratus }^{\mathrm{b}}\end{array}$ \\
\hline
\end{tabular}

${ }^{\mathrm{a}}$ Likely host species; ${ }^{\mathrm{b}}$ unlikely hosts = possible congener species.

inhibition assays and coagulation assays with zuphea $1 \mathrm{CE}$, revealed trypsin and thrombin inhibitors and anticoagulants. The anticoagulants delayed the recalcification time of human plasma, an indicator of blood coagulation via the intrinsic pathway (Abebe et al. 1996; see Tavares-Dia and Oliveira, 2009), and fibrinogen clotting time, a test estimating thrombin catalysis of fibrinogen into fibrin (Ricci et al. 2007; see Tavares-Dia and Oliveira, 2009).

Following fractionation by ion-exchange chromatography, 3 different bioactive peaks were isolated (P1, P2, P3). The first preparation (P1), displayed the strongest anti-trypsin activity, and reverse zymography revealed 3 trypsin inhibitors in this fraction with apparent molecular weights $\sim 18 \mathrm{kDa}, \sim 21 \mathrm{kDa}$ and $\sim 22 \mathrm{kDa}$. These trypsin inhibitors might target serine protease factors of the coagulation cascade (Watanabe et al. 2010) or serine proteases involved in other physiological processes (see Rimphanitchayakit and Tassaanakajon, 2010) in this gnathiid isopod. Indeed, serine protease inhibitors from the haemolymph of other crustaceans have been implicated in the immune response of these organisms, including melanization processes, and haemolymph clot formation (Kanost, 1999). Furthermore, serine protease inhibitors regulate digestive serine proteases (Morris and Sakanari, 1994; Azzolini et al. 2005), although in $P$. formica, digestion of the bloodmeal results primarily from cysteine protease activities (Manship et al. 2008). Characterization of trypsin inhibitors from homogenates of haematophagous ectoparasites, such as ticks and the horn fly (see Azzolini et al. 2003, 2005), have led to the identification of potential vaccine targets (see below).

Alongside these trypsin inhibitors, an anticoagulant(s) contained in the P1 fraction significantly delayed recalcification time of human plasma. Heating of the P1 preparation destroyed this anticoagulant activity, suggesting that the anticoagulant compound(s) present are proteinaceous; since P1 only slightly reduced thrombin interaction with fibrinogen, we hypothesize that the anticoagulant(s) inhibit a different factor(s) in the intrinsic pathway. However, the limited amount of gnathiid material available $\left(1 \mathrm{~g}\right.$ total represented $\sim 53 \times 10^{3}$ zuphea 1 juveniles) restricted further characterization of the anticoagulant(s) found, and the specific factor(s) in the coagulation cascade targeted by these compounds. In terrestrial blood-feeding arthropods, anticoagulant compounds identified so far predominantly target common factors to both intrinsic and extrinsic pathways, such as factor Xa or thrombin (see Stark and James, 1996; Valenzuela, 2002; Koh and Kini, 2009), and since thrombin activity was not reduced by the bioactive compounds contained in P1, these may inhibit factor Xa activity.

Finally, the semi-purified preparations P2 and P3 reduced fibrinogen-clotting time, and may contain the thrombin inhibitor(s) detected in the CE using a fluorogenic substrate Z-gly-pro-arg-MNA. Although not further characterized, it appears that both fractions contain different bioactive compound(s), eluted off the anion-exchange chromatography column at differing $\mathrm{NaCl}$ concentrations, which prevent the thrombin-fibrinogen interaction. These compounds, could possibly affect exosite I on thrombin, the specific fibrinogen active-binding site on thrombin (see Ciprandi et al. 2006; Ricci et al. 2007; Koh and Kini, 2009; Tanaka-Azevedo et al. 2010). In the case of the CE, the thrombin inhibitor(s) attenuated hydrolysis of the peptide synthetic substrate by thrombin; they may have bound the catalytic site of thrombin (Horn et al. 2000), or to different regions that prevented interaction of the catalytic site with the substrate (see Koh and Kini, 2009; Tanaka-Azevedo et al. 2010). The thrombin inhibitor(s) present in peaks $\mathrm{P} 2$ and P3, may function alongside anticoagulants present in $\mathrm{P} 1$ to inhibit clot formation, and/or may reduce thrombin mediated thrombocyte aggregation to the site of lesion (see Mann and Lorand, 1993; Dahlbäck, 2000; TavaresDias and Oliveira, 2009; Tanaka-Azevedo et al. 2010).

It is probable that the anticoagulant(s) identified in the present study are contained in the salivary glands of this gnathiid, in a similar manner to parasitic cymothoid isopods (Romestand and Trilles, 1976a, $b$ ), or they may be divided between the salivary glands 
and digestive tract (anterior hindgut) as reported in Rhipicephalus microplus (syn, Boophilus microplus) (Canestrini, 1888) ticks (Ricci et al. 2007) where they delay clot formation during digestion in the midgut. In larger blood-feeding ectoparasites, for example mosquitoes, tabanid flies or ticks, similar biochemical investigations have been conducted using proteins exclusively extracted from the salivary glands (Ribeiro et al. 1995; Stark and James, 1995, 1996; Kazimírová et al. 2001, 2002), or proteins collected after pilocarpine-induced salivation in ticks (Ciprandi et al. 2006). However, the size of the gnathiid juveniles and in particular the unfed zuphea 1 stage (1 mm each) (Upton, 1987), prevented dissection and separation of the salivary glands $(\sim 100-200 \mu \mathrm{m}$ in size) of $P$. formica, and therefore specific localization of the anticoagulant(s) could not be achieved. A recent report detailing the recovery of salivary secretions from the honeybee mite Varroa destructor (approximate size of $1-1.8 \mathrm{~mm}$ wide by $1.5-2 \mathrm{~mm}$ long) after inducing salivation using pilocarpine (Richards et al. 2011) could help future investigations into the localization and extraction of bioactive compounds from gnathiid isopods. In this context, a comparative study of anticoagulants present in unfed and fed stages of gnathiid juveniles, may reveal whether these bioactive compounds are restricted to a given stage, as previously reported for the cysteinelike proteolytic enzymes, which are more abundant in $P$. formica praniza stages (Manship et al. 2008). Interestingly, experiments conducted on anticoagulants of blood-feeding female mosquitoes revealed a strong factor Xa inhibitor in salivary gland extracts, whilst extracts of non-haematophagous male mosquitoes produced no delay in the recalcification time of human plasma (Stark and James, 1995). A comparative study of anticoagulant compounds found in the haematophagous juvenile stages and non-feeding males of $P$. formica (Monod, 1926) might offer an insight into the function of the male salivary glands.

Bioactive salivary compounds of arthropods of medical, veterinary and economic importance have been studied in detail (see Valenzuela, 2002; Ribeiro and Francischetti, 2003; Koh and Kini, 2009). A rationale for characterizing these salivary proteins is the design of arthropod and arthropod-borne control strategies, now advanced for anti-tick vaccines with successful applications in field studies (see Willadsen, 2006). In aquatic environments, such studies have been conducted only on the haematophagous marine ectoparasite Lepeophtheirus salmonis Krøyer, 1837 (Copepoda: Caligidae). Prostaglandin $\mathrm{E}_{2}$ (an antiinflammatory molecule) was identified in secretions of the copepod salmon louse (see Wagner et al. 2008), and knockdown of the prostaglandin $\mathrm{E}$ synthase 2 gene was attempted (Campbell et al. 2009) to identify targets for salmon vaccine development (Raynard et al. 2002). Gnathiid isopods cause tissue damage to their fish hosts whilst feeding (see Smit and Davies, 2004; Hayes et al. 2007, 2011). It is thus likely that as in other blood feeding ectoparasites, the isopod saliva contains a variety of immunomodulatory compounds (Singh and Girschick, 2003), such as prostaglandin $\mathrm{E}_{2}$ secreted by the salmon louse L. salmonis (see Wagner et al. 2008), alongside the potential trypsin inhibitors and anticoagulant(s) detected in this study.

A fuller understanding of host-preference or specificity is also vital in estimating the ecological and economic impact of gnathiid blood feeding. Molecular determination of host origin from the dietary content of invertebrates has been reported for predatory beetles (Zaidi et al. 1999), spiders (Agustí et al. 2003), blood-feeding ticks (Pichon et al. 2003), scavenging amphipod crustaceans (Blankenship and Yayanos, 2005), and recently the juveniles of gnathiid isopods from the Great Barrier Reef (GBR) (Nagel and Lougheed, 2006; Jones et al. 2007). The latter authors amplified fish DNA from the bloodmeal contents of 2 nocturnal species of gnathiids from the GBR, identifying 21 different host families, and finding differences in host-preference between these species.

Results presented here, reinforce the relevance of using molecular markers for identifying gnathiid host families and species, and it is surprising how many fish families/species were identified from relatively few gnathiids inhabiting mud banks at Wells-nextthe-Sea and the Dovey estuary. It is generally assumed that $18 \mathrm{~S}$ genomic rDNA evolves more slowly than $16 \mathrm{~S}$ mitochondrial rDNA, and is thus, highly conserved across a wide range of taxa (Pichon et al. 2003). This might explain our results, since some fish species apparently shared a high level of $18 \mathrm{~S}$ rDNA sequence conservation, and gnathiid hosts could be assigned only to their respective fish families. Sequences obtained using the universal (vertebrate and invertebrate) $16 \mathrm{~S}$ rDNA primers (Simon, 1991) were all of fish origin, corroborating findings by Blankenship and Yayanos (2005) that these primers preferentially amplify vertebrate DNA. Importantly, fish hosts were identified to the species level, by this marker, making it ideal for studying gnathiid hostpreferences as reported by Jones et al. (2007).

In the present study, hosts of $P$. formica pranizae belonged to different fish families to those reported for gnathiids on the GBR (Jones et al. 2007). Early laboratory feeding experiments using $P$. formica juveniles (Monod, 1926) and recent observations of gnathiids from the GBR (Nagel and Grutter, 2007), suggest adaptability by these isopods to available fish hosts. In the case of Paragnathia, this monotypic genus has been reported, as noted earlier, across Western Europe, North Africa and the Mediterranean basin (Monod, 1926; Upton, 1987; Menezes, 1984; Cadée et al. 2001; Silva et al. 2006; Kirkim et al. 2008) where juveniles likely feed on a variety of fish hosts according to availability. The host families 
obtained here agree with the findings of Monod (1926), who noted that $P$. formica fed on members of the Pleuronectiformes and Perciformes, and on European eels. Severe pathological effects on eels have been reported as well as host death in heavy infestations, or in captive environments (Mugridge and Stallybrass, 1983). Monod (1926) also observed an accidental association between $P$. formica and the European sprat, Sprattus sprattus (syn, Clupea sprattus) (Linnaeus, 1758), a species sharing over 98\% 16S rDNA homology with Clupea harengus (Atlantic herring). However, Monod's (1926) "accidental association" may not be so, since $C$. harengus DNA was amplified from 2 juvenile gnathiids at Wells-next-the-Sea. Finally, unidentified gnathiid isopods have recently been recorded on the European flounder off the coast of Portugal (Cavaleiro and Santos, 2009), and this fish appears to be a common host for P. formica (see Menezes, 1984), as reported here. The success of the host typing technique could lead to future identification of gnathiid hosts from larger specimen collections, to determine whether they are host-specific or respond to host availability. This is important since Marino et al. (2004) suggested that the opportunistic behaviour of juvenile gnathiids could result in infestations of captive or cultured fish worldwide, leading to economic loss.

In conclusion, this research was undertaken to provide important insight into the host-parasite interactions that occur between the post-marsupial stages of a gnathiid isopod and their host fishes. Together with our previous work on protein digestion in P. formica (see Manship et al. 2008), this constitutes the first thorough investigation of blood ingestion and host origin in $P$. formica juveniles, advancing considerably our understanding of feeding in this extraordinary gnathiid isopod.

\section{ACKNOWLEDGEMENTS}

We are grateful to the Royal Society for the Protection of Birds, Ynyshir Nature Reserve, for allowing access to the Dovey Estuary. Many thanks to Drs Idir Akhouayri, Polly Hayes, Mike Johnston and Professor Nico Smit for assisting with gnathiid collections. We are indebted to Drs Connor Jones and Laura Nagel for helpful advice on the sequencing of gnathiid material, and to the anonymous reviewers for their valuable comments for improving this manuscript.

\section{FINANCIAL SUPPORT}

The studentship awarded to B. M. by the Biomedical and Pharmaceutical Sciences Research Group, Kingston University, is gratefully acknowledged.

\section{REFERENCES}

Abebe, M., Ribeiro, J.M. C., Cupp, M.S. and Cupp, E. W. (1996). Novel anticoagulant from salivary glands of Simulium vittatum (Diptera: Simuliidae) inhibits activity of coagulation factor V. Fournal of Medical Entomology 33, 173-176.
Agustí, N., Shayler, P., Harwood, J. D., Vaughan, I. P., Sunderland, K. D. and Symondson, W. O.C. (2003). Collembola as alternative prey sustaining spiders in arable ecosystems: prey detection within predators using molecular markers. Molecular Ecology 12, 34673475. doi: 10.1046/j.1365-294X.2003.02014.X.

Andreotti, R., Gomes, A., Malavazi-Piza, K. C., Sasaki, S. D., Sampaio, C. A. M. and Tanaka, A.S. (2002). BmTI antigens induce a bovine protective immune response against Boophilus microplus tick. International Immunopharmacology 2, 557-563. doi: 10.1016/S1567-5769 (01)00203-X.

Azzolini, S. S. A., Sasaki, S. D., Campos, I. T. N., Torquato, R. J. S. Juliano, M. A. and Tanaka, A.S. (2005). The role of HiTI, a serine protease inhibitor from Haematobia irritans irritans (Diptera: Muscidae) in the control of fly and bacterial proteases. Experimental Parasitology 111 30-36. doi: 10.1016/j.exppara.2005.03.013.

Azzolini, S. S. A., Sasaki, S. D., Torquato, R. J. S., Andreotti, R., Andreotti, E. and Tanaka, A. S. (2003). Rhipicephalus sanguineus trypsin inhibitors present in the tick larvae: isolation, characterization, and partial primary structure determination. Archives of Biochemistry and Biophysics 417, 176-182. doi: 10.1016/S0003-9861(03)00344-8.

Blankenship, L.E. and Yayanos, A. A. (2005). Universal primers and PCR gut contents to study marine invertebrate diets. Molecular Ecology 14, 891-899. doi: 10.1111/j.1365-294X.2005.02448.X.

Cadée, G. C., Checa, A. G. and Rodriguez-Tovar, F. J. (2001). Burrows of Paragnathia (Crustacea: Isopoda) and Bledius (Arthropoda: Staphylinidae) enhance cliff erosion. International Fournal for Plant and Animal Traces 8, 255-260. doi: 10.1080/ 10420940109380193.

Campbell, E. M., Pert, C.C. and Bowman, A.S. (2009). RNAinterference methods for gene-knockdown in the sea louse, Lepeophtheirus salmonis: studies on a putative prostaglandin E synthase. Parasitology 136, 867-874. doi: 10.1017/S0031182009990357.

Cavaleiro, F. I. and Santos, M. J. (2009). Seasonality of metazoan ectoparasites in marine European flounder Platichthys flesus (Teleostei: Pleuronectidae). Parasitology 136, 855-865. doi: 10.1017/ S003118200900626X.

Ciprandi, A., De Olivera, S. K., Masuda, A., Horn, F. and Termignoni, C. (2006). Boophilus microplus: its saliva contains microphilin, a small thrombin inhibitor. Experimental Parasitology 114, 40-46. doi: 10.1016/j. exppara.2006.02.010.

Dahlbäck, B. (2000). Blood coagulation. The Lancet 355, 1627-1632. doi: 10.1016/S0140-6736(00)02225-X.

Davies, A. J. and Smit, N. J. (2001). The life cycle of Haemogregarina bigemina (Adeleina: Haemogregarinidae) in South African hosts. Folia Parasitologica 48, 169-177.

Doolittle, R.F. (2011). Coagulation in vertebrates with a focus on evolution and inflammation. Fournal of Innate Immunity 3, 9-16. doi: 10.1159/ 000321005 .

Dreyer, H. and Wägele, J. W. (2001). Parasites of crustaceans (Isopoda: Bopyridae) evolved from fish parasites: molecular and morphological evidence. Zoology 103, 157-178.

Ferreira, M. L., Smit, N. J., Grutter, A. S. and Davies, A. J. (2009). A new species Gnathia aureamaculosa n. sp. (Crustacea. Isopoda. Gnathiidae) parasitising teleosts from Lizard Island, Great Barrier Reef. Fournal of Parasitology 95, 1066-1075. doi: 10.1645/GE-1920.1.

Ferreira, M. L., Smit, N. J., Grutter, A.S. and Davies, A. J. (2010). Gnathia grutterae sp. nov. (Crustacea: Isopoda) parasitising representatives of the teleost families Balistidae and Labridae from Lizard Island, Great Barrier Reef, Australia. Zootaxa 2718, 39-50.

Hanspal, J.S., Bushell, G. R. and Ghosh, P. (1983). Detection of protease inhibitors using substrate-containing sodium dodecyl sulfatepolyacrylamide gel electrophoresis. Analytical Biochemistry 132, 288-293. doi: 10.1016/0003-2697(83)90010-6.

Hayes, P. M., Smit, N. J. and Davies, A. J. (2007). Pathology associated with parasitic juvenile gnathiids feeding on the puffadder shyshark, Haploblepharus edwardsii (Voight). Fournal of Fish Diseases 30, 55-58. doi: 10.1111/j.1365-2761.2007.00777.X.

Hayes, P. M., Smit, N. J., Grutter, A.S. and Davies, A. J. (2011) Unexpected response of a captive blackeye thicklip, Hemigymmus melapterus (Bloch), from Lizard Island, Australia, exposed to juvenile isopods Gnathia aureamaculosa Ferreira \& Smit. Fournal of Fish Diseases 34, 563-566. doi: 10.1111/j.1365-2761.2011.01261.X.

Horn, F., Coutinho dos Santos, P. and Termignoni, C. (2000). Boophilus microplus anticoagulant protein: an antithrombin inhibitor isolated from the cattle tick saliva. Archives of Biochemistry and Biophysics 384, 68-73. doi: 10.1006/abbi.2000.2076.

Jones, C. M., Nagel, L., Hughes, G. L., Cribb, T. H. and Grutter, A. S. (2007). Host specificity of two species of Gnathia (Isopoda) determined by 
DNA sequencing blood meals. International fournal for Parasitology 37, 927-935. doi: 10.1016/j.ijpara.2007.01.011.

Kanost, M. R. (1999). Serine proteinase inhibitors in arthropod immunity. Developmental \& Comparative Immunology 23, 291-301. doi: 10.1016/ S0145-305X(99)00012-9.

Kazimírová, M., Šulanová, M., Kozánek, M., Takáč, P., Labuda, M. and Nuttall, P.A. (2001). Identification of anticoagulant activities in salivary gland extracts of four horsefly species (Diptera, Tabanidae). Haemostasis 31, 294-305. doi: 10.1159/000048076.

Kazimírová, M., Šulanová, M., Trimnell, A. R., Kozánek, M., Vidlička, L., Labuda, M. and Nuttall, P. A. (2002). Anticoagulant activities in salivary glands of tabanid flies. Medical and Veterinary Entomology 16, 301-309. doi: 10.1046/j.1365-2915.2002.00379.X.

Kirkim, F., Kocataş, A., Katağan, T. and Sezgin, M. (2008). A report on parasitic isopods (Crustacea) from marine fishes and decapods collected from the Aegean Sea (Turkey). Türkive Parazitolöi Dergisi 32, 382-385.

Koh, C. Y. and Kini, R. M. (2009). Molecular diversity of anticoagulants from haematophagous animals. Thrombosis and Haemostasis 102, 437-453. doi: 10.1160/TH09-04-0221.

Mann, K. G. and Lorand, L. (1993). Introduction: blood coagulation. Methods in Enzymology 222, 1-10. doi: 10.1016/0076-6879(93)22003-X.

Manship, B. M. (2009). Aspects of development and feeding in Paragnathia formica (Hesse, 1864). Thesis (Ph.D.), School of Life Sciences, Kingston University, London.

Manship, B. M., Walker, A. J. and Davies, A. J. (2011). Brooding and embryonic development in the crustacean Paragnathia formica (Hesse, 1864) (Peracarida: Isopoda: Gnathiidae). Arthropod Structure Eळ Development 40, 135-145. doi: 10.1016/j.asd.2010.12.004.

Manship, B. M., Walker, A. J., Jones, L. A. and Davies, A. J. (2008). Characterisation of cysteine proteinase activities in the digestive tract of juvenile Paragnathia formica isopods, ectoparasites of estuarine fish. Marine Biology 153, 473-482. doi: 10.1007/s00227-007-0834-6.

Marino, F., Giannetto, S., Paradiso, M. L., Bottari, T., Devico, G. and Macri, B. (2004). Tissue damage and haematophagia due to praniza larvae (Isopoda, Gnathiidae) in some aquarium seawater teleosts. Diseases of Aquatic Organisms 59, 43-47. doi: 10.3354/dao059043.

McGinnis, S. and Madden, T.L. (2004). BLAST: at the core of a powerful and diverse set of sequence analysis tools. Nucleic Acid Research 32 , (WEB SERVER ISSUE):W20-W25. doi: 10.1093/nar/gkh435.

Menezes, J. (1984). Parasitose des mulets par les larves de Paragnathia. Fiches d'identification des maladies et parasites des poissons, crustacés et mollusques, 10. Conseil International pour l'Exploration de la Mer: Copenhagen, Denmark, 1-4

Monod, T. (1926). Les Gnathiidae. Essai monographique (Morphologie, Biologie, Systematique). Mémoires de la Société des Sciences Naturelles du Maroc 13, 1-668.

Morris, S. R. and Sakanari, J. A. (1994). Characterization of the serine protease and serine protease inhibitor from the tissue-penetrating nematode Anisakis simplex. The Fournal of Biological Chemistry 269, 27650-27656.

Mugridge, R. E. R. and Stallybrass, H. G. (1983). A mortality of eels, Anguilla anguilla L., attributed to Gnathiidae. Fournal of Fish Diseases 6, 81-82. doi: 10.1111/j.1365-2761.1983.tb00054.X.

Nagel, L. and Grutter, A. S. (2007). Host preference and specialization in Gnathia sp., a common parasitic isopod of coral reef fishes. Fournal of Fish Biology 70, 497-508. doi: 10.1111/j.1095-8649.2007.01320.X.

Nagel, L. and Lougheed, S. C. (2006). A simple molecular technique for identifying marine fish by sequencing bloodfeeding parasites. Fournal of Parasitology 92, 665-668. doi: 10.1645/GE-3541RN.1.

Pichon, B., Egan, D., Rogers, M. and Gray, J. (2003). Detection and identification of pathogens and host DNA in unfed host-seeking Ixodes ricinus L. (Acari: Ixodidae). Fournal of Medical Entomology 40, 723-731.

Raynard, R.S., Bricknell, I. A., Billingsley, P.F., Nisbet, A., Vigneau, A. and Sommerville, C. (2002). Development of vaccines against sea lice. Pest Management Science 58, 569-575. doi: 10.1002/ps.474. Ribeiro, J. M. C. and Francischetti, I. M. (2003). Role of arthropod saliva in blood feeding: sialome and post-sialome perspectives. Annual Review of Entomology 48, 73-88. doi: 10.1146/annurev.ento.48.060402.102812.

Ribeiro, J. M. C., Makoul, G. T., Levine, J., Robinson, D. R. and Spielman, A. (1985). Antihemostatic, anti-inflammatory, and immunosuppressive properties of the saliva of a tick, Ixodes dammini. Fournal of Experimental Medicine 161, 332-344. doi: 10.1084/jem.161.2.332.

Ribeiro, J. M. C., Schneider, M. and Guimarães, J. A. (1995). Purification and characterization of prolixin S (nitrophorin 2), the salivary anticoagulant of the blood-sucking bug Rhodnius prolixus. The Biochemical Fournal 308, 243-249.

Ricci, C. G., Pinto, A. F. M., Berger, M. and Termignoni, C. (2007). A thrombin inhibitor from the gut of Boophilus microplus ticks. Experimental and Applied Acarology 42, 291-300. doi: 10.1007/s10493-007-9097-7.
Richards, E. H., Jones, B. and Bowman, A. (2011). Salivary secretions from the honeybee mite, Varroa destructor: effects on insect haemocytes and preliminary biochemical characterization. Parasitology 138, 602-608. doi: 10.1017/S0031182011000072

Rimphanitchayakit, V. and Tassaanakajon, A. (2010). Structure and function of invertebrate Kazal-type serine proteinase inhibitors. Developmental and Comparative Immunology 34, 377-386. doi: 10.1016/j. dci.2009.12.004.

Romestand, B. and Trilles, J.P. (1976a). Au sujet d'une substance antithrombinique mise en évidence dans les glandes latéro-oesophagiennes de Meinertia oestroides (Risso, 1826) (Isopoda, Flabellifera, Cymothoidae: parasite de poissons). Zeitschrift für Parasitenkunde 50, 87-92.

Romestand, B. and Trilles, J.P. (1976b). Production d'une substance anticoagulante par les glandes exocrines céphalothoraciques des Isopodes Cymothoidae Meinertia oestroides (Risso, 1826) et Anilocra physodes (L., 1758) (Isopoda, Flabellifera, Cymothoidae). Comptes rendus hebdomadaires des Séances de l'Académie des Sciences 282, 663-665.

Sicard, M., Desmarais, E. and Lambert, A. (2001). Molecular characterisation of Diplozoidae populations on five Cyprinidae species: consequences for host specificity. Comptes Redus de l'Academie des SciencesSeries III - Sciences de la Vie 342, 709-717. doi: 10.1016/S0764-4469(01) 01352-X.

Silva, G., Costa, J. L., Raposo de Almeida, P. and Costa, M. J. (2006). Structure and dynamics of a benthic invertebrate community in an intertidal area of the Tagus estuary, western Portugal: a six year data series. Hydrobiologia 555, 115-128. doi: 10.1007/s10750-005-1110-8.

Simon, C. (1991). Appendix 3. In Molecular Techniques in Taxonomy (ed. Hewitt, G. M., Johnston, A. and Young, J. P.), pp. 345-355. SpringerVerlag, Berlin, Germany.

Singh, S. K. and Girschick, H. J. (2003). Tick-host interactions and their immunological implications in tick-borne diseases. Current Science 85, 1284-1298.

Smit, N. J. and Davies, A. J. (2004). The curious life-style of the parasitic stages of gnathiid isopods. Advances in Parasitology 58, 289-392. doi: 10.1016/S0065-308X(04)58005-3

Smit, N. J., Grutter, A. S., Adlard, R. D. and Davies, A. J. (2006). Hematozoa of teleosts from Lizard Island, Australia, with some comments on their possible mode of transmission and the description of a new hemogregarine species. Fournal of Parasitology 92, 778-788. doi: 10.1645/ GE-756R.1.

Stark, K. R. and James, A. A. (1995). A factor Xa-directed anticoagulant from the salivary glands of the Yellow Fever mosquito Aedes aegypti. Experimental Parasitology 81, 321-331. doi: 10.1006/expr.1995.1123.

Stark, K. R. and James, A.A. (1996). Anticoagulants in vector arthropods. Parasitology Today 12, 430-437. doi: 10.1016/0169-4758(96) 10064-8.

Stoll, C. (1962). Cycle évolutif de Paragnathia formica (Hesse) (Isopoda: Gnathiidae). Cahiers de Biologie Marine 3, 401-416.

Tanaka, A.S., Andreotti, R., Gomes, A., Torquato, R. J. S. Sampaio, M. U. and Sampiao, C. A. M. (1999). A double headed serine proteinase inhibitor - human plasma kallikrein and elastase inhibitor - from Boophilus microplus larvae. Immunopharmacology 45, 171-177. doi: 10.1016/ S0162-3109(99)00074-0.

Tanaka-Azevedo, A. M., Morais-Zani, K., Torquato, R. J. S. and Tanaka, A.S. (2010). Thrombin inhibitors from different animals. Fournal of Biomedicine and Biotechnology 2010, Article ID 641025. doi: $10.1155 / 2010 / 641025$.

Tanaka, K. (2007). Life history of gnathiid isopods-current knowledge and future directions. Plankton $\&$ Benthos Research 2, 1-11. doi: 10.3800/ pbr.2.1.

Tavares-Dias, M. and Oliveira, S. R. (2009). A review of the blood coagulation system of fish. Revista Brasileira de Biociências 7, 205-224.

Thompson, J. D., Higgins, D. G. and Gibson, T. J. (1994). CLUSTAL $\mathrm{W}$ : improving the sensitivity of progressive multiple sequence alignment through sequence weighting, position-specific gap penalties and weight matrix choice. Nucleic Acids Research 22, 4673-4680. doi: 10.1093/nar/ 22.22.4673.

Tinsley, M.C. and Reilly, S. (2002). Reproductive ecology of the saltmarsh-dwelling marine ectoparasite Paragnathia formica (Crustacea, Isopoda). Fournal of the Marine Biological Association of the United Kingdom 82, 79-84. doi: 10.1017/S0025315402005192.

Upton, N. P. D. (1987). Asynchronous male and female life cycles in the sexually dimorphic, harem-forming isopod Paragnathia formica (Crustacea, Isopoda). Fournal of Zoology (London) 212, 677-690. doi: 10.1111/j.14697998.1987.tb05964.X.

Valenzuela, J. G. (2002). High-throughput approaches to study salivary proteins and genes from vectors of disease. Insect Biochemistry 
and Molecular Biology 32, 1199-1209. doi: 10.1016/S0965-1748(02) 00083-8.

Wagner, G. N., Fast, M. D. and Johnson, S. C. (2008). Physiology and immunology of Lepeophtheirus salmonis infections of salmonids. Trends in Parasitology 24, 176-183. doi: 10.1016/j.pt.2007.12.010.

Watanabe, R.M. O., Soares, T.S., Morais-Zani, K., TanakaAzevedo, A. M., Maciel, C., Capurro, M. L., Torquato, R. J. S. and Tanaka, A. S. (2010). A novel trypsin Kazal-type inhibitor from Aedes aegypti with thrombin coagulant inhibitory activity. Biochimie 92, 933-939. doi: 10.1016/j.biochi.2010.03.024.

Willadsen, P. (2006). Vaccination against ectoparasites. Parasitology 133 (Suppl.) S9-S25. doi: 10.1017/S0031182006001788.

Zaidi, R. H., Jaal, Z., Hawkes, N. J., Hemingway, J. and Symondson, O. C. (1999). Can multiple-copy sequences of prey DNA be detected amongst the gut contents of invertebrate predators? Molecular Ecology 8, 2081-2087. doi: 10.1046/j.1365-294x. 1999.00823.X. 